\title{
BRINGING ENERGY TRADE INTO THE WTO: THE HISTORICAL CONTEXT, CURRENT STATUS, AND POTENTIAL IMPLICATIONS FOR THE MIDDLE EAST REGION
}

\author{
Susan L. Sakmar, JD, LL.M.*
}

\section{INTRODUCTION}

Two emerging energy issues at the World Trade Organization (WTO) ${ }^{1}$ have the potential to significantly impact the oil producing countries in the Middle East North Africa (MENA) region. The first is a call for a new round of WTO trade negotiations that would address the energy sector and seek to treat oil and gas like other traded goods. The second is the growing demand to subject energy services to freer trade under the General Agreement on Trade in Services (GATS). ${ }^{2}$

As oil prices topped seventy dollars per barrel in 2006, it became clear that the world was entering a period of historic transition where calls for new energy policies and "energy security" grew louder by the day. ${ }^{3}$ Indeed, energy security has become the new lens through which governments view international relations. The record-high oil prices led Peter Mandelson, the European Union's top trade official, to call for a new round of global trade talks ${ }^{4}$ focusing on energy and subjecting trade in oil and gas to the same rules

* Professor of Law (adjunct), University of San Francisco Law School (USF). Ms. Sakmar received her LL.M. in International Law from Georgetown Law Center and her JD from USF School of Law where she teaches a seminar on International Trade Law. Her research is focused on Energy, International Trade, and Middle East economies. This article was originally presented at the $6^{\text {th }}$ International Conference of the Middle East Economic Association, Dubai, United Arab Emirates, March 14-16, 2007. Ms. Sakmar is licensed to practice law in California and was an attorney in San Francisco prior to teaching.

1. See generally General Agreement on Tariffs and Trade: Multilateral Trade Negotiations Final Act Embodying the Results of the Uruguay Round of Trade Negotiations, 33 INT'L LEGAL MATERIALS 1125, (1994). The WTO was established on January 1, 1995, and provides a forum for implementing the multilateral trading system, negotiating new trade agreements and resolving trade disputes. Id. The Agreement Establishing the World Trade Organization (WTO Agreement) incorporates the original General Agreement on Tariffs and Trade (GATT), which continues to apply to issues not covered by the more specific agreements negotiated during the Uruguay Round. Id.

2. General Agreement on Trade: Multilateral Trade Negotiations, Final Act Embodying the Results of the Uruguay Round of Trade Negotiations, Annex 1B, Article X, Apr. 15, 1994,

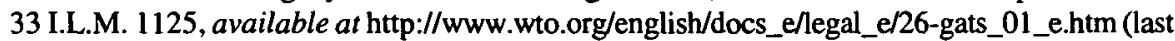
visited Jan. 1, 2008) [hereinafter GATS].

3. Saint Petersburg Summit 2006, Global Energy Security, available at http://peopleandplanet.org/dl/climate/g8_energy_security.pdf (last visited Jan. 1, 2008).

4. Marc Champion \& Juliane von Reppert-Bismark, Politics \& Economics: EU Trade Chief Poses WTO Rules in Energy Sector, WALL ST. J., June 23, 2006, at A6. 
as other goods under the General Agreement on Tariffs and Trade (GATT). ${ }^{5}$

Due to the strategic importance of petroleum and the initial nonparticipation of most key energy exporters in the early GATT rounds, energy products have largely been exempted from multilateral trading rules. Instead, international trade in petroleum has been treated as a special case subject to political pressures and national security exceptions under the GATT. This does not mean that multilateral trade rules do not apply to petroleum products; there is nothing in GATT expressly excluding such products. Moreover, some fiftyone countries and the European Union (EU) have been using the Energy Charter Treaty (ECT), ${ }^{6}$ which provides a multilateral framework for cooperation on energy-related policymaking and serves as a basis for international rules on energy. The EU's proposal for a new round of WTO talks focused specifically on energy would undoubtedly be based upon the ECT.

Although a new round of talks focusing on energy is likely years away, a push for freer trade in those energy services already within the current Doha Development Agenda (Doha Round) has already occurred. ${ }^{7}$ In February 2006, a group of demandeurs from energy-importing nations formally submitted to the WTO a request asking a group of developing nations, including Egypt, Kuwait, Nigeria, Qatar, and the United Arab Emirates, to open up their markets to freer trade in energy services. ${ }^{8}$ The proposal seeks liberalization in core activities of oil and gas production, processing, and distribution.

Because the current WTO proposals must be viewed in the context of the historical and more recent concerns over energy security, Section II of this paper discusses the geopolitics of oil and some of the current market forces driving the calls for trade rules focused on energy. Section III addresses the EU's proposal for a new round of trade talks on energy and looks at the current treatment of energy under GATT/WTO rules. Section III also discusses the ECT which might be used as the basis for the EU's proposed trade round. Since it is unlikely a new trade round focusing on energy will take place in the

5. General Agreement on Tariffs and Trade, Oct. 30, 1947, 61 Stat. A-11, 55 U.N.T.S. 187 [hereinafter GATT]. available

6. Council and Commission Decision 98/181, 1998 O.J. (L69) (EC, ECSC, Euratom), ex.europa.eu/smartapi/cgi/sga_doc?smartapi!celexplus!prod!DocNumber\&lg=en\&type_doc=De cision\&an_doc $=1998 \&$ nu_doc $=181$; see also Energy Charter, http://www.encharter.org/index.php?id=1\&L=0.

7. WTO member governments agreed to launch a new round of trade negotiations at the Fourth Ministerial Conference held in Doha, Qatar, in November 2001. World Trade Organization, Doha Development Agenda: Negotiations, implementation and development, http://www.wto.org/english/tratop_e/dda_e/dda_e.htm (last visited Jan. 1, 2008). They also agreed to work on other issues, in particular, the implementation of the present agreements. Id. The entire package is called the Doha Development Agenda (DDA). Id.

8. International Forum on Globalization, Collective Request in Energy Services, available at http://www.ifg.org/pdf/collective-request-in-energy-services.pdf (last visited Jan. 1, 2008) [hereinafter Collective Request]. 
near future, Section IV of this paper analyzes the demandeurs' proposal regarding freer trade in energy services. Section $\mathrm{V}$ analyzes the potential implications these trade proposals might have on the oil-producing countries in the MENA region. Lastly, Section IV concludes that uncertainty in the world's energy markets will result in a continued focus on energy security and the ways in which trade rules can evolve to promote energy security.

\section{THE GEOPOLITICS OF OIL}

There is no doubt that energy markets and energy security have changed dramatically in the three decades since the oil supply disruptions of the 1970s. "Up to 1970, the Seven Sisters (Royal Dutch Shell, Exxon, Gulf, Texaco, BP, Mobil, and Standard Oil of California (Chevron)) dominated world petroleum trade." These vertically integrated companies produced, shipped, refined, marketed and sold petroleum products all over the world. "As the main suppliers of crude oil to most refiners worldwide" and also the main distributors of refined products, "they could readily adjust supply and demand, thereby greatly influencing price."10

Concern over the exploitation of their resources led Saudi Arabia, Iran, Iraq, Kuwait, and Venezuela to form the Organization of Petroleum Exporting Countries (OPEC) in $1960 .^{11}$ OPEC wielded very little power during the $1960 \mathrm{~s}$ due to a worldwide oil glut combined with pricing wars between oil companies. $^{12}$ In the 1970 s, world events significantly changed OPEC's influence in the world energy markets. By that time, many countries had taken control of the production of energy within their borders by nationalizing their oil industries. In the United States, oil production had peakedbut consumption had more than doubled. For the first time, the United States was forced to turn to the world oil markets, and in particular to OPEC member states, to satisfy its rising demand for oil. ${ }^{13}$ The United States' increased reliance on foreign oil

9. Fred Bosselman et al., ENergy EConomics AND the ENVIRONMENT, CaSes AND MATERIALS 413 (2006) (citing THE CENTER FOR STRATEGIC AND INTERNATIONAL STUDIES, THE Critical LinK: Energy and National Security IN THE 1980s 126-27 (Ballinger, rev. ed. 1982)). These major oil companies received concessions from the oil-bearing countries under which the companies developed oil fields in certain areas for a certain period of time. Id. In return, the companies paid royalties or excised taxes to the host governments. Id. This royalty system gave the companies complete control over production, pricing, and exports. Id. Although the companies bore all the risk of failure, they also reaped all of the financial rewards of success. Id.

10. $1 d$.

11. BosSELMAN ET AL., supra note 9, at 126-27.

12. Id.

13. Id. at 411 (citing Daniel YeRgIN, The PRIZE: The EPIC QUEST For OlL, MONEY AND POWER 395-96, 531-32, 544, 567, 569 (1991). The early 1970s also brought environmental concerns regarding oil exploration to the forefront in the United States; many promising areas were closed to oil exploration. Id. 
would ultimately lead to several "oil shocks" in the 1970 s. ${ }^{14}$

\section{A. The Oil Shocks}

The Yom Kippur war of 1973 led to what is known as the first oil shock. ${ }^{15}$ After Arab nations declared an embargo on the shipment of oil to the United States and other countries friendly to Israel, "U.S. refineries scrambled for oil and shortages sent crude prices soaring."16 "A second oil shock hit in 1979, when the Shah of Iran was ousted and replaced by a . . . government headed by the Ayatollah Khomeini." 17 In response to the taking of hostages by Iran, U.S. President Jimmy Carter banned the importation of Iranian produced oil. The government of Iran responded with an embargo and oil prices skyrocketed again. $^{18}$

A third oil shock occurred in the mid-1980s, although this time the consequences ran in the opposite direction, with plummeting prices that led exporters scrambling for markets and buyers scrambling for the lowest price. ${ }^{19}$ This oil shock was caused in part by technological innovations, such as higher fuel efficiency standards, and growing tensions between Iran and Saudi Arabia, leading the Saudi government to "open its taps.",20

After the price of oil plunged to $\$ 10$ per barrel in 1986 , oil prices stayed relatively stable, in the range of $\$ 15$ to $\$ 19$ per barrel through the end of 1999. ${ }^{21}$ This price range represented a consensus of both OPEC and nonOPEC nations, all of whom had an interest in stabilizing oil prices at approximately $\$ 18$ per barrel. ${ }^{22}$ By early 2000 , the price of crude oil had crept back to over $\$ 30$ per barrel, with the United States urging OPEC "to increase output to moderate the impact on importing countries['] economies."23

\footnotetext{
14. BoSSELMAN ET AL., supra note 9, at 126-127.

15. Id. at 411 .

16. Id. at 412 .

17. Id.

18. Id.

19. Id.

20. Id. at $419-20$.

21. Id. at 421 .
}

22. Id. at 421 . As a large domestic producer of oil, " $\$ 10$ barrel oil would cripple the United States' domestic oil industry with its high-cost wells." Id. It has been reported that George H.W. Bush. "warned the Saudis on a visit in 1986 that the US would impose a tariff on imported oil if prices remained so low." Id. "Whether this warning was real or not, the December 1986 meeting of OPEC ministers adopted a 'reference price' of $\$ 18$ a barrel, and OPEC members agreed to quotas" to ensure a price increase. Id. (citing Yergin, supra note 13, at 750-64).

23. Bosselman ET AL., supra note 9, at 423. Although there is often the misconception that OPEC sets the price of oil, this is not the case; oil trades as a commodity and oil prices are set on the commodity markets such as the New York Mercantile Exchange (NYMEX). Id. at 421. Spot markets (short-term buying and selling) determine industry pricing. Id. However, since OPEC's oil exports represent about $55 \%$ of the oil traded internationally, there is no doubt that OPEC has a strong influence on the oil market, especially if OPEC reduces or increases its 


\section{B. Energy Security in the $21^{\text {st }}$ Century}

It appears that even OPEC has had only limited success in maintaining fixed prices when market forces shift; and prices continued to rise relentlessly from 2000 to 2006 , topping $\$ 70$ per barrel in the fall of $2006 .{ }^{24}$ By this point, it seemed the global energy system was stretched to its breaking point. ${ }^{25}$ Although much debate over "peak oil" theories has occurred, there is now general consensus that global demand for energy is rising and at least some question whether global supplies of conventional oil can keep pace with demand. $^{26}$

According to the International Energy Agency (IEA), ${ }^{27}$ the demand for energy is estimated to rise by more than $50 \%$ by the year 2030, approximately $80 \%$ of which will still be met by fossil fuels. ${ }^{28}$ Nearly half of the global oil demand growth over the next ten years will occur in the Asia Pacific region, with China and India accounting for most of the demand. ${ }^{29}$ The IEA has cautioned that since non-OPEC production of conventional crude oil and natural gas is set to peak within a decade, "OECD and developing Asian countries will become increasingly dependent on imports." ${ }^{\text {,30 }}$ The Middle East is the only region with enough proven oil reserves to meet this rising demand over the next decades. $^{31}$ Of the twenty countries with the largest proven reserves, seven are in the MENA region and account for approximately $62 \%$ of the world's total reserves. ${ }^{32}$

"The concentration of oil production in a small group of countries with large reserves - notably the Middle East OPEC members and Russia - will increase their market dominance and their ability to impose higher prices."33

level of supply. OPEC.ORG, What is Opec?, Oct. 2007, available at http://www.opec.org/library/what\%20is\%200PEC/whatisOPEC.pdf.

24. Oil prices remained volatile in 2007 and briefly skirted with $\$ 100$ a barrel in early 2008. See generally, James Burkhard and Ruchir Kadakia, Ten Times Ten: What Future for Oil Prices?, Feb. 12, 2008, WSJ Special Advertising Section, Focus on Energy: CERAWeek 2008.

25. The New Energy Security Paradigm, WORLD ECONOMIC FORUM, Spring 2006, at 7.

26. For an excellent discussion of various Peak Oil theories, see BOSSELMAN ET AL., supra note 9 , at $423-28$.

27. International Energy Agency, About the IEA, http://www.iea.org/about/index.asp (last visited Jan. 1, 2008) ("The International Energy Agency acts as an energy policy advisor to [twenty-six] member countries" and was created in response to the oil shocks of the 1970s.).

28. Global Energy Security, supra note 3.

29. The New Energy Security Paradigm, supra note 25, at 14.

30. World Energy Outlook 2006, Summary and Conclusions, available at http://www.iea.org/Textbase/npsum/WEO2006SUM.pdf (last visited Jan. 1, 2008).

31. Id.

32. IEA Report (citing OL and GaS JouRnal, (2006)); see also British Petroleum, Chart of Proved Reserves, http://www.bp.com (last visited Jan. 1, 2008) (follow "Statistical Review of World Energy" hyperlink; then download "Historical Data Work Book") (noting that by the end of 2005 , the Middle East region had 742.7 billion barrels of proved oil reserves accounting for $61.9 \%$ of the total world proved oil reserves).

33. IEA Report, supra note 32 (citing Sam Fletcher, CERA: Crude Oil Production Capacity to Grow $25 \%$ in 10 Years, OIL AND GAS JouRnal, Dec. 19, 2005). Countries in the EU face additional concerns regarding the transit of oil and natural gas and supply disruptions 
Moreover, the IEA has expressed concerns that "OPEC's price and production policies and national policies on developing reserves are extremely uncertain." 34 This uncertainty is exacerbated by the fact that large portions of the world's reserves of oil are found in countries that maintain restrictions on foreign investment. Thus, there is no guarantee future investment in these countries will be large enough to boost capacity sufficient to meet the projected increase in demand. ${ }^{35}$ Based on the IEA's assessment, it is easy to see why, in the context of energy security, uncertainty over supply from the Middle East ranks as a top issue of concern for governments and CEOs alike. ${ }^{36}$

Against this backdrop, heads of states from the Group of Eight (G8) industrialized leaders met in Saint Petersburg, Russia in July 2006. ${ }^{37}$ During the meeting, G8 leaders agreed that ensuring an "uninterrupted, sufficient, reliable and secure supply of energy at prices reflecting economic fundamentals and market principles is a challenge for the entire world. ${ }^{38}$ To meet this challenge, leaders acknowledged the serious impediments they would have to address, including:

- high and volatile oil prices;

- growing demand for energy;

- increasing import dependence in many countries;

- enormous investment requirements along the entire energy chain;

- the need to protect the environment and to tackle climate change; ${ }^{39}$

- vulnerability of critical energy infrastructure;

- political instability, natural disasters and other threats. ${ }^{40}$

To meet these challenges, leaders pledged to take several actions directly related to trade rules. First, they vowed to increase the transparency, predictability, and stability of global energy markets. Leaders stated that efforts would be made to "advance transparency; to deepen and spread the rule of law; to establish and strengthen predictable efficient fiscal and regulatory regimes; and to encourage sound energy supply and demand policies."41 A clear and stable regulatory framework was deemed essential to global energy security. ${ }^{42}$

Second, leaders vowed to improve the investment climate in the energy sector. G8 leaders noted that "ensuring an adequate global energy supply will require trillions of U.S. dollars in investment throughout the entire energy chain by 2030." As such, leaders pledged to work to "reduce barriers to energy

from Russia. Id.

34. World Energy Outlook, supra note 30, at 15.

35. Id.

36. The New Energy Security Paradigm, supra note 25, at 6.

37. The $\mathrm{G} 8$ consists of Canada, France, Germany, Italy, Japan, Russia, United Kingdom, and United States. G8 Agree to Promote Energy Security, BRIDGES TRADE BIoRes, Vol. 6, No. 14, July 28, 2006, available at http://www.ictsd.org/biores/06-07-28/story2.htm.

38. Global Energy Security, supra note 3.

39. Although an important component of energy policy, a detailed discussion of environmental measures and their relation to energy policy is beyond the scope of this paper.

40. Global Energy Security, supra note 3.

41. Id.

42. Id. 
investment and trade." The reduction of such barriers would allow

companies from energy producing and consuming countries [to] invest in and acquire upstream and downstream assets internationally in a mutually beneficial way and respecting competition rules to improve the global efficiency of energy production and consumption. Market-based investment flows between and among nations will also enhance energy security by increasing confidence in access to markets or sources of supply. $^{43}$

\section{THE CALL FOR A NEW WTO ROUND ON ENERGY}

Building on the pledges made at the G8 Summit, in June 2006, EU Trade Commissioner Peter Mandelson called for a new round of WTO negotiations that would focus on the energy sector and seek to treat oil and gas like other traded goods. ${ }^{44}$ Mr. Mandelson acknowledged that energy goods have generally been used as a source of political strength; thus, trade in energy has largely been exempted from the rules of trade based on national security issues. ${ }^{45}$ Nonetheless, he stated that a global forum, such as the WTO, where most parties are at the table, "is the best way to attain "structural change"" in energy issues. $^{46}$ To entice energy producers to come to the table, $\mathrm{Mr}$. Mandelson suggested offering more security in their export markets and increased investment. ${ }^{47}$

By November 2006, it seemed clear that leaders in developed countries, particularly the EU and U.S., were looking to expand and enhance trade policy to include energy. In a speech to a conference on strategic energy policy, $\mathrm{Mr}$. Mandelson argued that "more international rules" and "trade policy can make an important contribution to energy security and to calming some of the existing tensions in the system."48

\section{A. Current Treatment of Energy under WTO/GATT Rules}

Although generally applicable trade rules, such as most favored nation treatment (MFN) ${ }^{49}$ and national treatment, ${ }^{50}$ apply to trade in energy products,

43. Id.

44. Champion \& von Reppert-Bismark, supra note 4.

45. Id.

46. Id.

47. EU Trade Chief Moots, supra note 45.

48. Peter Mandelson, Conference on Strategic Energy Policy, Mandelson Calls for "Negotiated Solutions" to Govern Trade in Energy, Brussels (Nov. 21, 2006), available at http://trade.ec.europa.eu/doclib/docs/2006/november/tradoc_131225.pdf.

49. GATT art. I(1). Article I(1) of GATT sets forth the MFN clause and provides that 
the initial non-participation of most key energy exporters in early GATT rounds precluded significant discussion of energy issues. ${ }^{51}$ Indeed, when OPEC was founded in Baghdad in 1960, none of the founding members - Kuwait, Iraq, Iran, Saudi Arabia, and Venezuela -were contracting parties to the GATT. ${ }^{52}$ The composition of both OPEC and the WTO has grown over the years and seven of the eleven OPEC countries are now members of the WTO: Indonesia, Nigeria, Kuwait, Venezuela, Qatar, the United Arab Emirates (UAE), and Saudi Arabia. ${ }^{53}$ Notably, Saudi Arabia, a key energy exporter, only recently acceded to the WTO after years of protracted negotiations. ${ }^{54}$

Additionally, the strategic importance of petroleum to the world economy has meant petroleum has been historically treated in a largely political context, and not within the GATT multilateral trade rules. ${ }^{55}$ Indeed, since there appears to have been a "'gentlemen's agreement,' not to bring up petroleum issues" in early GATT negotiations, issues related to trade in petroleum "[do] not appear to be set out in any written documents."56

The United Nations Conference on Trade and Development (UNCTAD) research also concluded that:

there were no negotiations under the Uruguay Round on tariffs applied to petroleum and petroleum products (with the exception of those involving the EU). However, their levels in the main importing markets (EU, Japan, and the United States) are generally very low and in many cases not bound. This fact

"any advantage, favour, privilege or immunity granted by any contracting party to any product originating in or destined for any other country shall be accorded immediately and unconditionally to the like product originating in or destined for any other country shall be accorded immediately and unconditionally to the like product originating in or destined for the territories of all other contracting parties." Id.

50. GATT art. III(4). Article III provides, with respect to internal taxation and domestic laws, regulations and requirements, imported products shall be accorded treatment "no less favourable" than the treatment accorded to domestic products. Id.

51. See Melaku Geboye Desta, The Organization of Petroleum Exporting Countries, the World Trade Organization, and Regional Trade Agreements, 37 JOURNAL OF WORLD TRADE 523, 529 (2003) [hereinafter Desta, Organization].

52. Melaku Geboye Desta, OPEC and the WTO: Petroleum as a Fuel for Cooperation in International Relations (2004), http://www.mees.com/postedarticles/oped/a47n10d01.htm; see also Desta, Organization, supra note 53. For the full article see Melaku Geboye Desta, OPEC, the WTO, Regionalism and Unilateralism, JOURNAL OF WORLD TRADE, vol. 37 (2003) 43.

53. Members include: Algeria, Angola, Indonesia, Iran, Iraq, Kuwait, Libya, Nigeria, Qatar, Saudi Arabia, UAE, and Venezuela. OPEC, http://www.opec.org/aboutus/ (last visited Jan. 1, 2008). Compare OPEC member list with WTO member list. World Trade Organization, http://www.wto.org/english/thewto_e/whatis_e/tif_e/org6_e.htm (last visited Jan. 1, 2008).

54. WTO General Council Successfully Adopts Saudi Arabia's Terms of Accession, WTO 2005 Press Release, Nov. 11, 2005, available at http://www.wto.org/english/news_e/pres05_e/pr420_ehtm (last visited Feb. 16, 2008).

55. See generally U.N. Conference on Trade \& Dev., Trade Agreements, Petroleum and Energy Policies (2000), available at http://www.unctad.org/en/docs/itcdtsb9_en.pdf (last visited Jan. 1, 2008) [hereinafter UNCTAD].

56. Id. at 15 . 
confirms that tariffs in the energy sector typically reflect more the dictates of energy policy - securing adequate supplies than a trade policy in the classic sense. ${ }^{57}$

In summary, UNCTAD concluded that the Uruguay Round had hardly any impact on MFN tariffs for crude oil and only a limited impact on petroleum products. $^{58}$

"The U.S. tariffs on crude oil are very low but unbound. This means that there is no legal guarantee that this tariff will remain at such a low level." ${ }^{, 59}$ In other words, "the [U.S.] could impose a much higher tariff rate without violating WTO [rules]." ${ }^{60}$ With record-high oil prices, it seems unlikely tariffs will be an issue. Hypothetically, there is a risk that some countries might face increased tariffs for national security reasons. It is also possible that a future U.S. administration might consider imposing an oil-import fee, either to raise revenue or to discourage the consumption of hydrocarbons. This hypothetical risk might be reason enough for oil exporting countries to use the binding of U.S. tariffs as a bargaining chip in any future trade negotiations in the energy sector.

Of greater significance, at least from the stand point of oil exporting countries, is the issue of internal taxes levied on consumption. Petroleumexporting countries have historically believed that the high-consumption and excise taxes imposed by certain importing countries on gasoline and other petroleum products undermines the ability to derive income from their own natural resources. ${ }^{61}$ However, since these taxes are imposed in a nondiscriminatory manner on both imports and domestic production, highconsumption and excise taxes are not inconsistent with GATT obligations. ${ }^{62}$ Regardless, they can be the subject of negotiated concessions. Thus, it is possible that the binding and reduction of high-consumption and excise taxes could be included in a future round of WTO negotiations.

Another specific exception in the GATT applicable to the petroleum sector is the national security exception in Article XXI, which has been called "a major loophole in GATT law." 63 The strategic importance of oil has led the

57. Id. at 26.

58. Id. at 27.

59. Id. at 11 (emphasis added).

60. Id.

61. Id. at 27. UNCTAD research found that "[a]ccording to some estimates provided by OPEC, in 1996, the G-7 nations' (United States, Canada, Japan, Germany, Italy, United Kingdom, and France) oil tax incomes totaled U.S. \$270 billion, while OPEC Petroleum Export Revenues were U.S. $\$ 160$ billion." Id. at 27 n.27 (citing OPEC.ORG, What is Opec?, Oct. 2007, available at http://www.opec.org/library/what\%20is\%20OPEC/whatisOPEC.pdf.).

62. Id.

63. UNCTAD, supra note 57 , at 118 . Article XXI provides:

Nothing in this Agreement shall be construed

(a) to require any contracting party to furnish any information the disclosure of which it considers contrary to its essential security interests; or 
United States to impose import restrictions on several occasions. "64 "These restrictions, which have variously been [applied] on a global or country-specific basis," would most likely fall under Article XXI if challenged under the WTO. 65 "States have traditionally [been accorded] a high degree of discretion in invoking [Article XXI and] it has been generally accepted that States have almost total discretion in [determining] what constitutes an 'essential security interest." "66 As such, it is possible that Article XXI might be used to justify import or export restrictions in a wide range of circumstances.

Although there is no explicit exclusion of petroleum products from the scope of the multilateral trade agreements under the WTO, a review of GATT jurisprudence leads to the conclusion that a combination of factors has essentially led to their exclusion from this forum. ${ }^{67}$ More recently, energy trade issues have been the source of protracted negotiations as more energy exporting countries, such as Saudi Arabia, have sought entry into the WTO. The United States, in particular, uses the accession process as an opportunity to obtain commitments and concessions from the acceding countries. "From the U.S. perspective, accession negotiations have [a distinct] advantage[] over other WTO talks ... . [since they] are [almost] entirely one-sided: the acceding country must pay an 'entry fee' to the existing members, but can demand no concessions in return."68

\section{B. The Energy Charter Treaty as a Model for Future WTO Negotiations}

The EU has thus far been the main proponent of the call for a new WTO round to address energy issues. As such, it is likely that any new round sought by the EU would look to the provisions of the Energy Charter Treaty as a model. The ECT entered into legal force in April 1998 and as of January 2007 had been signed or acceded to by fifty-one states plus the European Communities. $^{69}$

(b) to prevent any contracting party from taking any action which it considers necessary for the protection of its essential security interests

(i) relating to fissionable materials or the materials from which they are derived;

(ii) relating to the traffic in arms, ammunition and implements of war and to such traffic in other goods and materials as is carried on directly or indirectly for the purpose of supplying a military establishment;

(iii) taken in time of war or other emergency in international relations; or

(c) to prevent any contracting party from taking any action in pursuance of its obligations under the United Nations Charter for the maintenance of international peace and security.

Id. at $28-29$.

64. UNCTAD, supra note 57, at 118 .

65. Id. at 118.

66. Id. at 29 .

67. UNCTAD, supra note 57 , at 118 .

68. Id. at 115.

69. Energy Charter, supra note 6. Members of the ECT include: Albania, Armenia, Austria, Australia, * Azerbaijan, Belarus* Belgium, Bosnia and Herzegovina, Bulgaria, Croatia, 
When the ECT first came into existence in the early 1990s, almost half of the states that were to join the ECT were not contracting parties to the GATT. This was the main reason for making the GATT 1947 (and later WTO rules) applicable in the ECT for trade relations involving non-WTO members. ${ }^{70}$ Consequently, the ECT allowed non-WTO members to benefit from stable, predictable and non-discriminatory trade rules in the energy sector. ${ }^{71}$ The ECT also serves as a "stepping stone" for signatory states" seeking to join the WTO by providing a "useful external anchor for trade reforms" and by allowing "[states] to familiarise themselves with the practices and disciplines that WTO membership entails." 73

The primary goal of the ECT is to "strengthen the rule of law on energy issues, by creating a level playing field of rules to be observed by all participating governments, thereby mitigating risks associated with energyrelated investments and trade." ${ }^{, 74}$ According to the EU's energy policy and the ECT framework, the "right" energy framework is "one that is open to investment, innovation and trade, and one that encourages energy efficiency.",75 Any new WTO round proposed by the EU would seek to address these issues.

The ECT is both narrower and broader than the WTO rules. It is narrower because it "does not provide for legally binding tariff commitments and the WTO Agreements on Trade in Services (GATS) and Trade-Related Intellectual Property Rights (TRIPS) do not apply." ${ }^{, 76}$ The ECT is broader than the WTO in two significant ways. First, unlike the WTO, the ECT provides broad protections for energy sector investments. Second, the ECT more thoroughly addresses issues such as energy transit, and includes a distinctive

Czech Republic, Cyprus, Denmark, Estonia, European Communities, Finland, France, Georgia, Germany, Greece, Hungary, Iceland,* Ireland, Italy, Japan, Kazakhstan, Kyrgyzstan, Latvia, Liechtenstein, Lithuania, Luxembourg, Malta, Moldova, Mongolia, Netherlands, Norway,* Poland, Portugal, Romania, Russian Federation,* Slovakia, Slovenia, Spain, Sweden, Switzerland, Tajikistan, The former Yugoslav Republic of Macedonia, Turkey, Turkmenistan, Ukraine, Uzbekistan, United Kingdom. (* denotes ratification pending). Energy Charter, Members \& Observers, http://www.encharter.org/index.php?id=61 \& $\mathrm{L}=0$ (last visited Jan. 1, 2008). Observer states to the ECT include: Afghanistan, Algeria, People's Republic of China, Canada, Islamic Republic of Iran, Republic of Korea, Kuwait, Morocco, Nigeria, Oman, Pakistan, Qatar, Saudi Arabia, Serbia, Tunisia, United Arab Emirates, United States of America, Venezuela. Id.

70. See Energy Charter;

About the

Charter, http://www.encharter.org/index.php?id=7\&L=0 (last visited Jan. 1, 2008).

71. See id.

72. Azerbaijan, Belarus, Bosnia \& Herzegovina, Kazakhstan, Russian Federation, Tajikistan, Turkmenistan, Ukraine, Uzbekistan (as of January 2007). Energy Charter: 1998 Trade Amendment, http://www.encharter.org/index.php?id=26\&L $=0$ (last visited Jan. 1, 2008).

73. Id.

74. Energy Charter: About the Charter, supra note 72.

75. Henning Christophersen, Chairman of the Energy Charter Conference, The Role of Gov'ts and Int'l Orgs. in Promoting Energy Security (Oct. 25, 2006), available at http://www.encharter.org/fileadmin/user_upload/Conferences/2006_Octii/Christophersen.pdf.

76. Energy Charter: Treaty Provisions, http://www.encharter.org/index.php?id $=40 \& L=0$ (last visited Jan. 1, 2008). 
mechanism to resolve energy transit disputes. ${ }^{77}$

In terms of investment, the ECT recognizes that " $[t]$ here is a huge need for new investment in order to meet [the] global demand for energy.", A significant risk to energy security is a framework that does not promote investment in the most efficient energy supply or energy-saving projects. ${ }^{79}$ The ECT seeks to reduce this risk by creating a favorable investment climate based on openness, consistency, and non-discrimination.

The ECT takes a balanced approach to investors' access to resources. The ECT is explicit in confirming national sovereignty over energy resources: each member country is free to decide how, and to what extent, its national and sovereign energy resources will be developed, and also the extent to which its energy sector will be opened to foreign investments. ${ }^{80}$ There is an explicit requirement, however, that rules on the exploration, development, and acquisition of resources must be publicly available, non-discriminatory, and transparent.

Once a foreign investment is made in line with a country's national legislation, the Treaty is designed to provide a reliable and stable interface between this investment and the host government. The Treaty protects foreign investors against non-commercial risks such as discriminatory treatment, direct or indirect expropriation, or the breach of individual investment contracts. The need for stability in the relationship between investors and host governments is particularly acute in the energy sector, where projects tend to be long-term and highly capital intensive. ${ }^{81}$

The ECT's rules significantly mitigate the risk to member nations and provide for international arbitration if a dispute arises. ${ }^{\mathbf{8 2}}$

The ECT also recognizes that transit is indispensable for ensuring secure energy flows, and transit issues are gaining in importance with the increased interdependency and integration of energy markets. In recent years, transit has been an especially important issue in the EU due to Russia's continued disputes with Belarus over the price of gas which has led to numerous supply disruptions. ${ }^{83}$ The ECT is the only multilateral agreement directly addressing

77. Energy Charter: Trade \& Transit, http://www.encharter.org/index.php?id=5\&L=0 (last visited Jan. 1, 2008).

78. Energy Charter: Investment, http://www.encharter.org/index.php?id $=6 \& L=0$ (last visited Jan. 1, 2008).

79. Id.

80. $I d$.

81. Id.

82. Energy Charter: Dispute Settlement, http://www.encharter.org/index.php?id=269\&L=0 (last visited Jan. 1, 2008).

83. Michael Connolly, Resisting Moscow's Energy Imperialism, WALL ST. J., Nov. 13, 
the complex political, economic, and legal issues associated with energy transit. In this regard, the ECT is broader than the WTO/GATT in developing a specific transit-related regime for the energy sector and requires states to:

to take the necessary measures to facilitate transit of energy, consistent with the principle of freedom of transit, and to secure established energy flows. Transit countries are also under an obligation not to interrupt or reduce existing transit flows, even if they have disputes with another country concerning this transit. ${ }^{84}$

\section{FREER TRADE IN ENERGY SERVICES}

Although a new round of WTO negotiations focused on energy is unlikely in the near term, some members, particularly the United States, will continue to pursue more open trade in energy services under the current Doha Round. As a leader in providing "top quality services," the United States has long advocated that liberalizing services "promote[s] the interchange of goods, people, and ideas ... [and] [t]o the extent that the services sector is opened and modernized, countries will receive an economic boost." States has indicated that it is seeking "broad removal of foreign barriers" in various services sectors, including energy services. ${ }^{86}$

\section{A. Overview of GATS and Oil Services}

The GATS ${ }^{87}$ was created with essentially the same objectives as its counterpart directed toward trade in goods (the General Agreement on Tariffs and Trade (GATT)). These objectives include creating a credible and reliable system of international trade rules, non-discrimination among all participants, stimulating economic activity through guaranteed policy bindings, and

2006; see also Russia and Belarus: Loveless Brothers, EcoNomisT, Jan. 11, 2007, available at http://www.economist.com/background/displaystory.cfm?story_id=8521935. Russia and Belarus have been in a protracted dispute over the price of gas demanded by Russia. The dispute ultimately led Russia to stop pumping oil into a pipeline that crosses Belarus and delivers $12.5 \%$ of the EU's oil needs; thus, disrupting supplies to Poland, Germany, and other Central European countries. Id.

84. Energy Charter: Trade \& Transit, supra note 79.

85. Press Release, Office of United States Trade Representative, The United States Announces Proposals for Liberalizing Trade in Services (July 1, 2002), available at http://www.ustr.gov/Document_Library/Press_Releases/2002/July/United_States_Announces_P roposals_for_Liberalizing_Trade_in_Services.html [hereinafter Liberalization Proposal].

86. Fact Sheet, Office of United States Trade Representative, Free Trade in Services: Opening Dynamic New Markets, Supporting Good Jobs (May 31, 2005), available at http:// http://www.ustr.gov/Document_Library/Fact_Sheets/2005/Free_Trade_in_Services_Opening_D ynamic_New_Markets,_Supporting_Good_Jobs.html.

87. GATS, supra note 2. 
promoting trade and development through progressive liberalization. ${ }^{88}$

Obligations contained in the GATS may be categorized into two broad groups: general obligations and specific commitments. General obligations apply automatically to all Members and services sectors, and include MFN Treatment ${ }^{89}$ and transparency. Transparency means GATS members are required to publish all measures of general application and establish national enquiry points mandated to respond to other Members' information requests. ${ }^{90}$

Specific commitments concern market access and national treatment in designated sectors. Market access is negotiated as a commitment in specified sectors. Such commitments may be made subject to various types of limitations that are enumerated in Article XVI(2), such as limitations imposed on the number of services suppliers, service operations, or employees in the sectors. ${ }^{91}$

A commitment to national treatment implies that the Member concerned will not operate discriminatory measures for the benefit of domestic services or service suppliers. The key requirement is not to modify, in law or fact, the conditions of competition in favor of the Member's own service industry. Again, the extension of national treatment in any particular sector may be made subject to conditions and qualifications. ${ }^{92}$

Each WTO Member is required to have a Schedule of Specific Commitments, which identifies the services for which the Member guarantees market access and national treatment and any limitations that may be attached. The Schedule may also be used to assume additional commitments such as the implementation of specified standards or regulatory principles. Commitments are undertaken with respect to each of the four different modes of service supply. ${ }^{93}$

Most schedules consist of both sectoral and horizontal sections. The "Horizontal Section" contains entries applied across all sectors subsequently listed in the schedule. Horizontal limitations often refer to a particular mode of supply, notably commercial presence and the presence of natural persons. The "Sector-Specific Sections" contain entries that apply only to the particular service. Any Member is free to expand or upgrade its existing commitments at any time. ${ }^{94}$

According to the WTO, energy services were not negotiated as a separate sector during the Uruguay Round. Rather, the Uruguay Round was only the first step in a long-term process of multilateral rulemaking and trade

88. Id.

89. Under Article II of GATS, Members must extend to all other Members "treatment no less favourable than it accord[ed] to like services and service suppliers of any other country." GATS art. II.

90. GATS art. III.

91. GATS art. XVI.

92. GATS art. XVII.

93. GATS art. XX.

94. GATS art. XXI. 
liberalization. ${ }^{95}$ Although a few WTO members have made limited commitments in the energy-related services, "the vast majority of the global energy services industry is not covered by specific commitments under the GATS." 96

The Doha Round of services negotiations began in January 2000 and included negotiations in energy services. Pursuant to the Doha mandate, participants in the energy services negotiations have exchanged requests and offers since 2002. ${ }^{97}$ The Doha Round was scheduled to conclude in 2005 but the deadline was extended and the Round ultimately suspended in July $2006{ }^{98}$ Negotiations under Doha resumed in early $2007^{99}$ and it is hoped that the negotiations will conclude by the end of $2008 .{ }^{100}$

A chief difficulty in the services negotiations has been the definition and classification of energy services. The WTO "Services Sectoral Classification List," commonly known as "W/120," does not include a separate classification for energy services. ${ }^{101}$ Rather, three specific subclasses of energy services are

95. Although services currently account for over $60 \%$ of global production and employment, services represent no more than $20 \%$ of total trade. This share is likely to increase significantly in the coming years, as more services become internationally mobile. Id. Service industries are a major component of U.S. economic activity, accounting for $80 \%$ of U.S. employment and 63\% of the U.S. Gross Domestic Product (GDP). Press Release, Office of the United States Trade Representative, United States Announces Proposals for Liberalizing Trade in Services (July 1, 2002), available at http://www.ustr.gov/Document_Library/Press_Releases/2002/July/United_States_Announces_P roposals_for_Liberalizing_Trade_in_Services.html?ht=. The United States is also the world's largest exporter of services and U.S. services exports have more than doubled over the last ten years, increasing from $\$ 137$ billion in 1990 to $\$ 279$ billion in 2000 . Id.

96. WTO, Services: Sector by Sector, Energy Services, http://www.wto.org/english/tratop_e/serv_e/energy_e/energy_e.htm (last visited Jan. 1, 2008).

97. Irene Musselli \& Simonetta Zarrilli, Oil and Gas Services: Market Liberalization and the Ongoing GATS Negotiations, 8 J. INT'L ECON. L. 551, 551-52 (2005). GATS negotiations take place in Geneva through a process of formal "requests and offers," whereby countries seeking to access the service sectors of other nations "request" that a country "offer" to make specific commitments to open its market to more foreign service suppliers. Id. "Requested" or "demanded" countries are not obliged to offer anything to the "requesting" or "demanding" countries, but are often subjected to intense political pressure to do so. Id. A fundamental principle in GATS is "progressive liberalization," which stipulates governments may initially exempt certain sectors today or place limitations on the extent that they commit these sectors to the GATS. Id. These exemptions and limitations are targeted for removal in successive rounds of GATS negotiations. Id.

98. WTO, 2006 News Items, General Council Supports Suspension of Trade Talks, Task Force Submits "Aid for Trade" Recommendations (July 27-28, 2006) http://www.wto.org/english/news_e/news06_e/gc_27july06_e.htm.

99. WTO, 2007 News Items, Lamy: "We have resumed negotiations fully across the board." (Feb 7, 2007), available http://www.wto.org/english/news_e/news07_e/gc_dg_stat_7feb07_e.htm.

100. WTO, 2008 News Items, Lamy: "We are on the last lap." (Feb. 5, 2008), available at http://www.wto.org/english/news_e/news07_e/gc_dg_stat_7feb07_e.h.

101. Id. at 559. The WTO Services Sectoral List is commonly known as W/120. It is a non-negotiated document created by the WTO Secretariat as a reference point in scheduling specific commitments. Id. at 559 n.9. 
included in different sectoral categories in W/120: (1) "services incidental to energy distribution[;]" (2) "services incidental to mining" (both services listed as a sub-class of 'Other Business Services'); and (3) "pipeline transportation of fuel" (listed as a subclass of 'Transport Services'). ${ }^{102}$

In addition, a number of other activities related to the energy services sector "chain cut horizontally across the W/120 list," including "architectural and engineering services, construction work for civil engineering, wholesale and retail trade services with respect to fuels and energy equipment, transportation services, and several specific financial services." 103 A "number of specific energy services are not yet specified in the existing GATS classification" and the "W/120 does not appear to fully reflect the commercial reality of the energy supply system." 104

A group of WTO Members, the so-called "Friends of Energy Group," has been working on a new classification of energy services that will better reflect the current market realities for the energy sector. ${ }^{105}$ Two such lists have been submitted to the attention of the whole WTO membership. ${ }^{106}$ The first list is sponsored by Chile, the European Communities, Japan, and the United States. ${ }^{107}$ This proposed list does not advocate a new classification structure; rather, it is based on the United Nations Provisional Central Product Classification (UNCPC) list ${ }^{108}$ "and major segments of the energy services activities." 109

\section{B. Demandeurs WTO Submission}

In February 2006 a group of demandeurs from several major energy importers and exporters ${ }^{110}$ formally submitted to the WTO a collective request asking for a target group of developing nations ${ }^{111}$ to open up their markets to

102. Id. at 559.

103. Id.

104. Id.

105. Id.

106. Id.

107. Id. (citing Job (03)/89, May 12, 2003).

108. Id. at $560 \mathrm{n} .11$ (noting the UNCPC "does not list energy services as a separate category [but that] Annex I, however, provides a compendium of energy-related products listed under different headings in the [UN]CPC, including energy-related services").

109. Id. at $560 \mathrm{n} .12$ (noting "activities are divided into four broad categories: exploration and development services; pipeline transportation of fuels and energy transmission and distribution services; energy commercialization services; and other services important to the provision of energy, energy products and fuels").

110. The demandeurs include: Australia, Canada, the European Communities, Japan, Norway, The Kingdom of Saudi Arabia, Republic of Korea, Separate Customs Territory of Taiwan, Penghu, Kinmen and Matsu, Singapore, and the United States. Collective Request, supra note 8 , at 2 .

111. The target group includes six of seven OPEC Members who are also WTO Members, excluding Venezuela. Also receiving the request were seven Latin American countries and almost every major developing nation with growing energy needs, including China, India, and 
freer trade in energy services. The overall objective of the request is to ensure the ongoing service negotiations result in "a high level of liberalization for the supply of services relevant for a Member's energy sector." The stated goal was a "thriving energy sector - including energy services" as a "basic element of economic well-being." 112 The demandeurs' request elaborated:

The availability of varied sources of energy at competitive prices contributes to a nation's ability to compete in the world marketplace. ... Moreover, modern energy services provide the means to develop energy resources in an environmentally sound manner and in ways that promote responsible and efficient development and use of energy resources. ${ }^{113}$

The three primary issues in the request are: ownership of energy resources, sectoral coverage, and specific commitments.

\section{Ownership of Energy Resources}

In a separate document ${ }^{114}$ issued to clarify their request, the demandeurs reiterated that the request does not extend to ownership of natural resources. States have sovereign rights over the natural resources found in their territories; therefore, states are empowered to regulate the exploration, development and exploitation of these resources. However, these states often grant these rights to state-owned or private companies (or joint companies in which the state-owned company owns a majority share) in the form of a license or on the basis of a production-sharing agreement.

To carry out production, the licensee often contracts with the government of the sovereign nation for a number of specific activities. The scope of such requests includes a range of energy services provided by energy service suppliers to the licensee; however, requests do not address or define the relationship between states and those entities authorized to produce the natural resource.

\section{Sectoral Coverage}

"The collective request on Energy services results from a convergence of views on where energy services can be found in the W/120 classification."115

South Africa. International Forum on Globalization, The Other Oil War: Halliburton's Agenda at the WTO (June 2006) (prepared by Victor Menotti), available at www.ifg.org/reports/WTOenergy-services.htm [hereinafter Other Oil War].

112. Collective Request, supra note 8, at 2.

113. Id.

114. International Forum on Globalization, Plurilateral Negotiations on Energy Services (May 3, 2006), available at http://www.ifg.org/pdf/plurilateral-negotiations-on-energyservices.pdf.

115. Id. at 2 . 
The illustrative list includes a wide range of services such as surveying, mapmaking, locating mineral deposits, project management services for developing exploitation of an oil field or wind power project, design services for a mining plant, on land site preparation, on land rig installation, drilling, testing and analysis services, and many others. ${ }^{116}$ The list is expressly "not exhaustive,"117 and the demandeurs requested that "commitments be taken with the widest possible sectoral coverage." 118

\section{Specific Commitments}

The GATS distinguishes between four modes of supplying services: (1) cross-border supply is defined to cover services flows from the territory of one Member into the territory of another Member (e.g. banking or architectural services transmitted via telecommunications or mail); (2) consumption abroad refers to situations where a service consumer (e.g. tourist or patient) moves into another Member's territory to obtain a service; (3) commercial presence implies that a service supplier of one Member establishes a territorial presence, including through ownership or lease of premises, in another Member's territory to provide a service (e.g. domestic subsidiaries of foreign insurance companies or hotel chains); and (4) presence of natural persons consists of persons of one Member entering the territory of another Member to supply a service (e.g. accountants, doctors, or teachers). ${ }^{119}$

The demandeurs made the following requests regarding specific commitments:

Mode 1: Since a number of energy services may be and are currently often provided through cross-border mode of supply, for those services we request:

- Substantial reduction of market access limitations

- Removal of existing requirements of commercial presence

Mode 2: We request commitments whenever technically feasible

Mode 3: Commercial presence being an essential mode of supply for most energy service activities, we make the following request:

- Removal or substantial reduction of foreign equity limitations

- Substantial elimination of joint ventures and joint operations requirements for foreign service suppliers

- Removal or substantial reduction of economic needs tests

- Elimination of discriminatory licensing procedures

116. Id.

117. Id. at 2-5.

118. Collective Request, supra note 8, at 3 .

119. GATS art. I. 
Mode $4:^{120}$

- Make commitments in accordance with paragraph 1(d) of Annex $\mathrm{C}$ of the Hong Kong Ministerial Declaration

- No general exclusion of energy services from horizontal Mode 4 commitments. ${ }^{121}$

Although the demandeurs' request was designed to "jump start" the WTO services negotiations, very little attention was given to the request. ${ }^{122}$

\section{IMPLICATIONS FOR THE MENA REGION}

At this point, only very broad suggestions and proposals have been made regarding a trade round focused on energy and the liberalization of energy services. Moreover, there has been very little public debate or scholarly work focused on energy issues under the WTO. Nonetheless, there are several foreseeable implications for the MENA region. First, as more energy producers accede to the WTO, the WTO is likely to exert greater influence over the energy sector. Second, current WTO members will continue to push for increased access to the energy sector in the MENA region. Finally, to effectively participate in the multilateral trading regime and have an impact on whether energy trade is brought into the WTO, oil producing countries in the MENA region need to increase their trade capacity.

\section{A. The WTO'sInfluence Over The Energy Sector Is Likely To Increase}

The composition of the WTO's membership is one of the determinants of how quickly energy issues evolve under the WTO. Saudi Arabia became the 149th member of the WTO in December 2005. ${ }^{123}$ This is significant because it brings an important part of energy trade under the purview of the WTO's multilateral rules.

Saudi Arabia's accession was the result of difficult and protracted negotiations with the United States. Under accession to the WTO, Saudi Arabia committed to opening additional service markets to foreign investment, which will provide substantial benefit to the U.S. services sector in particular. In the United States, the Coalition of Service Industries was consulted continuously throughout the negotiation process to ensure U.S. service

120. For this element, the United States is not a requesting Member, but shall be deemed a recipient. Collective Request, supra note 8, at 4 n.1.

121. Id. at 4.

122. Press Release, Office of United States Trade Representative, United States Is Active Participant in Coalition to Jump Start WTO Services Negotiations (Feb. 28, 2006), available at http://www.ustr.gov/Document_Library/Press_Releases/2006/February/United_States_is_Active _Participant_in_Coalition_to_Jump_Start_WTO_Services_Negotiations.html.

123. WTO General Council Successfully Adopts Saudi Arabia's Terms of Accession, WTO 2005 Press Release, Nov. 11, 2005, available at http://www.wto.org/english/news_e/pres05_e/pr420_e.htm. 
industries would garner the best concessions from Saudi Arabia. ${ }^{124}$ Some of the greatest concessions made by Saudi Arabia were in the energy services sector.

Although current Saudi Arabian regulations close oil exploration, drilling, and production to foreign investment, ${ }^{125}$ the investment climate is expected to improve as Saudi Arabia implements its commitments under the WTO. In fact, "[f]oreign investment in the full upstream hydrocarbon sector will be vital in the coming decades if Saudi Arabia hopes to expand production and refining capacity to meet expected growth in international demand."126 In contrast to the upstream sector, foreign investment in refining and petrochemical development is not prohibited, and significant foreign investment in the downstream Saudi energy sector already exists. ${ }^{127}$

All eyes will be on Saudi Arabia as it implements the various agreements under the WTO over the next few years. Several other important energy producers, such as Russia, Kazakhstan, and Algeria are in line to accede to the WTO as well. ${ }^{128}$ Thus, as the traded portion of oil and gas consumption increases, there will likely be growing discussion over how to eliminate various energy-trade barriers. ${ }^{129}$ There is no doubt that the WTO will take the lead in

124. Letter from Norman R. Sorensen, Chairman, Coal. of Services Indus., to the Senate Finance Committee and the House Ways and Means Committee (Aug. 17, 2005) (noting that the US service sector has expanded markedly in recent years and "now represents $80 \%$ of U.S. private sector GDP, $75 \%$ of private sector employment, and $30 \%$ of total U.S. exports") (on file with Indiana International \& Comparative Law Review).

125. However, in July 2003, "the Ministry of Petroleum announced an auction to open up part of the Ghawar area to foreign investors for non-associated natural gas exploration. In January 2004, six companies competed in the auction for the three offered blocks" with the winners being Russia's Lukoil, China's Sinopec, and a joint bid by Italy's Eni and Spain's Repsol. United States Department of State, 2006 Investment Climate Statement - Saudi Arabia (Feb. 2006), available at http://www.state.gov/e/eeb/ifd/2006/62029.htm [hereinafter 2006 Investment Climate Statement]. Each signed a forty-year exploration and production contract. $I d$. The deal marked the first time since the 1980 nationalization of ARAMCO foreign companies have been allowed to explore in Saudi Arabia. Id. No further deals have authorized foreign investment. $I d$.

126. Id.

127. Exxon Mobil and Shell are the largest foreign investors in Saudi Arabia; both are 50\% partners in refineries with Saudi Aramco. Id. Saudi Aramco is currently engaged in selecting foreign bidders to join as equity partners in two new export refineries scheduled for completion in 2009, at an estimated cost of $\$ 4$ to 5 billion each. Id. Several US firms submitted bids on the refinery projects. In addition, Exxon Mobil, Chevron Texaco, and Shell have formed joint ventures with the Saudi Arabian Basic Industries Corporation (SABIC) to build world-scale petrochemical plants that utilize feedstock from Saudi Aramco. Id.

128. WTO News: Speeches - DG Pascal Lamy, Lamy highlights environment dimensions of the trade talks, May 10, 2006, available at http://www.wto.org/english/news_e/sppl_e/sppl25_e.htm.

Three important OPEC members, Iraq, Iran, and Libya, remain outside the WTO.

129. According to Fatih Birol, chief economist at the IEA, there has been growing discussion over how to eliminate energy-trade barriers as the traded portion of oil and gas consumption increases. "The IEA projects that the traded portion of global oil production will rise from $50 \%$ today to $66 \%$ in 25 years, while traded gas would rise from $18 \%$ to $33 \%$." Fatih Birol, Chief Economist, Int'l Energy Agency, Testimony at United States Senate Committee on 
this discussion.

\section{B. Current WTO Members Will Continue to Push for Increased Access to Energy in the MENA Region}

In light of the ongoing difficulties in concluding the Doha Round, it is unlikely that a new round of trade negotiations focused on energy will start anytime soon. However, a senior WTO official has said a proposal to launch an energy-focused round of talks "would be given serious thought,"130 thereby opening the door for a future round of trade talks focused on the energy sector.

If any new round is proposed, the EU will most likely push for the ECT as model, but will want even broader commitments over transit issues to resolve its ongoing disputes with Russia. From the perspective of the EU, and in line with the ECT framework and the Saint Petersburg Plan of Action, a new round would seek to address issues particularly related to investment, transparency, transit, and supply.

The EU's proposal for a new round of energy talks demonstrates that $\$ 70$ per barrel oil coupled with increased demand and tight supply has officials around the globe searching for ways to rebalance the energy market more in favor of consuming nations. One possible way to achieve this balance would be to bring energy trade directly under the WTO.

Bringing trade in oil directly under the WTO might also limit OPEC's influence over the global supply of oil and world energy prices. , During the 1970s, the United States viewed the potential power that OPEC and its member states had over the price of oil as an impediment to orderly and stable markets and a threat to the national interests of the United States. ${ }^{131}$ This bias against OPEC continues to this day. ${ }^{132}$ One way to limit OPEC's control over world energy markets would be to move more energy trade under the purview of the WTO's multilateral agreements.

Even in the absence of a new round of talks devoted to energy, there is likely to be continued pressure put on countries in the MENA region to further liberalize their markets. For example, Saudi Arabia has promised additional measures "to create a more investor friendly environment and promote increased foreign investment, such as a pledge to set up a special court for trade

Energy and Natural Resources, Oil Market Outlook and Policy Implications (Jan. 10, 2006) [hereinafter Fatih Birol Testimony].

130. Champion \& von Reppert-Bismark, supra note 4.

131. Former U.S. Secretary of State Henry Kissinger stated "both the Nixon and Ford Administrations had no higher priority than to bring about a reduction of oil prices by breaking the power of OPEC." Desta, Organization, supra note 53, at 527 (citing HENRY KISSINGER, YEARS OF RENEWAL: MEMOIRS, Vol. 3 668-69 (1999)).

132. In the fall of 2006, OPEC nations announced steps to boost world oil prices. This led U.S. Senator Frank R. Lautenberg (D-NJ) to call on President Bush to file an action in the WTO against OPEC's plan to limit crude oil production, claiming a violation of Article XI of GATT. Press Release, Senator Frank R. Lautenberg, Lautenberg Calls on Bush to File WTO Complaint against OPEC to Prevent the Cartel from Boosting Oil Price (Oct. 11, 2006), available at http://lautenberg.senate.gov/newsroom/record.cfm?id=264566\&. 
disputes between foreign and Saudi firms."

\section{The MENA Region Needs to Increase Its Trade Capacity}

Many of the countries in the MENA region have only recently joined the WTO. As such, these countries need to increase their trade capacity and reassess their trade policies to become more competitive in the global trading regime. The WTO's recent Trade Policy Review (TPR) ${ }^{134}$ of the UAE supports this assertion.

The WTO's TPR found the UAE's generally liberal economy has grown by $6 \%$ per year on average over the past decade and $9 \%$ in the period between 2003 and 2005. "[D]espite some diversification, the UAE still depends on crude oil and gas exports for a significant share of its national income."135 The Report by the Secretariat noted that "[t]he entire oil and gas sector, as well as electricity and water utilities, remains state controlled, with foreign participation generally in the form of minority partnerships." 136 The Secretariat further noted that "internal barriers to trade, resulting largely from the absence of a competition policy, institutional weaknesses, and restrictions on foreign participation in the economy, are impediments to doing business in the UAE and are hindering the diversification into services, a sector that is rapidly becoming a strategic priority." "137

The Report by the UAE recognized the need to strengthen its trade capacity and indicated a number of ways in which it would do so. These included a desire to partner with a selected UAE university to create a degree in WTO issues, the organization of numerous seminars and training on WTO issues, and having UAE candidates attend various training sessions at the WTO. ${ }^{138}$ Issues related to energy were not specifically mentioned, but it would

133. 2006 Investment Climate Statement, supra note 126.

134.

Trade Policy Reviews are an exercise, mandated in the WTO agreements, in which member countries' trade and related policies are examined and evaluated at regular intervals. Significant developments that may have an impact on the global trading system are also monitored. For each review, two documents are prepared: a policy statement by the government of the member under review, and a detailed report written independently by the WTO Secretariat. These two documents are then discussed by the WTO's full membership in the Trade Policy Review Body (TPRB).

www.wto.org.

135. Press Release, WTO, A Generally Liberal Economy Whose Performance Could Further Improve with Structural Reform (April 24, 26, 2006), available at http://www.wto.org/english/tratop_e/tpr_e/tp263_e.htm [hereinafter WTO, Generally Liberal Economy].

136. WTO Secretariat, Trade Policy Review: United Arab Emirates, WT/TPR/S/162 (Mar. 20, 2006), available at http://www.wto.org/english/tratop_e/tpr_e/s162-0_e.doc [hereinafter WTO Secretariat, Trade Policy Review].

137. WTO, Generally Liberal Economy, supra note 136.

138. WTO Secretariat, Trade Policy Review, supra note 137. 
be wise for MENA governments to undertake internal assessments to understand the full consequences of binding any part of their energy sectors to WTO rules.

An insight into the possible future agenda for negotiations related to energy issues can be gleaned by examining how these issues have been treated at the regional level. In many cases, the approaches taken in regional agreements have appeared on the multilateral stage. Thus, countries in the MENA region should become familiar with other regional agreements on which various energy proposals could be based, including, but not limited to, the ECT.

\section{CONCLUSION}

During 2006 and 2007, the world's energy markets were faced with increased demand for crude oil and numerous disruptions to supply. This combination of factors led to high and volatile prices. ${ }^{139}$ With oil prices already topping the inflation-adjusted record price set during the second oil shock, it seems likely that 2008 will be just as volatile as $2006-2007 .^{140}$

The continued uncertainty and volatility in the energy markets will keep issues related to energy security at the top of the global political agenda for the foreseeable future. Indeed, the continued focus on energy security was recently reflected at CERA Week 2008, where the conference topic was "Quest for Security, Strategies for a New Energy Future."141

To ensure energy security in the future, the EU and the United States will most likely continue to push for more rules to govern the trade in energy. While the ECT and the WTO have laid the foundation for countries to address the trade-related aspects of energy, these rules need to evolve to address energy trade more comprehensively. The inability of trade ministers to conclude the Doha Round has, for the moment, stalled the movement calling for a new trade round to regulate energy. Undoubtedly, this pause will be brief since energy security remains a top priority for policy leaders in the $21^{\text {st }}$ Century.

139. According to the Energy Information Administration which provides official energy statistics from the U.S. Government, the spot price of West Texas Intermediate (WTI) crude averaged $\$ 66.02$ per barrel in 2006 and $\$ 72.32$ per barrel in 2007. EIA, Short-Term Energy Outlook, Feb. 12, 2008, available at http://www.eia.doe.gov.steo.

140. Jad Mouawad, Oil Tops Inflation-Adjusted Record Set in 1980, The New York Times, March 4, 2008, available at http://www.nytimes.com/2008/03/04/business/worldbusiness/04oil.html?em\&ex=12047796 (noting that oil prices hit a record high on March 3, 2008 of $\$ 103.95$ a barrel which exceeded the record of $\$ 39.50$ a barrel which equals $\$ 103.76$ today when adjusted for inflation).

141. Organized by Cambridge Energy Research Associates, "CERAWEEK has been ranked one of the five most influential senior executive conferences in the world, and the only one focused on a specific industry. CERAWEEK brings together almost 2,000 leaders from more than 55 countries to discuss and debate the global energy future." Focus on Energy: CERAWeek 2008, Special Advertising Section, Wall Street Journal, available at http://www2.cera.com/ceraweek2008/ CERAWeekWSJ2008-02-13.pdf. 
